\title{
Migrations, the labour market and poverty in Greater Buenos Aires
}

\author{
Rosalía Cortés and Fernando Groisman
}

Rosalía Cortés

Research Professor

-rcortes@fibertel.com.ar

Fernando Groisman

Guest Research Fellow

$\propto$ fgroisman@tutopia.com

Latin American Faculty

of Social Sciences

(Economics and Technology

Section) and

National Council for Scientific and Technological Research

(FLACSO-CONICET), Argentina

his study analyses the labour behaviour of two segments of migrants - one coming from the provincial areas of Argentina and the other from neighbouring countries - in Greater Buenos Aires during the 1990s. Their labour trajectories were different: the economic activity of the migrants from neighbouring countries increased, but there was an expansion in the proportion of internal migrants in the "not working" category. A process of replacement of internal migrants with migrants from neighbouring countries took place: the latter worked in precarious, poorly-paid occupations, while the internal migrants swelled the ranks of the "structural poor": persons with no trade, only occasional employment, and few possibilities of improving their situation in the near future. 
I

\section{Introduction}

This study analyses the differences that occurred in the course of the 1990s in the labour situation of recent internal migrants and migrants from neighbouring countries (hereinafter also referred to as "cross-border migrants") who arrived in Greater Buenos Aires during that period. ${ }^{1}$ In that decade, the low fixed exchange rate attracted migrants from Chile, Paraguay, Uruguay, Bolivia and latterly Peru, even in the years of recession, which represented a difference from the behaviour of internal migration flows.

From the mid-1970s and during the following decade -that of the debt crisis- the stagnation of the product and of the demand for labour had caused a slowing-down in the growth rates of the labour force, employment and income. The recessionary context affected the rate of internal and international migrations to the metropolitan area, which fell below their historical levels between 1975 and 1980 because of the return of migrants to their provinces or countries of origin. ${ }^{2}$

The international migrants from neighbouring countries who arrived in Greater Buenos Aires had historically shared a number of common characteristics with migrants from provinces in the interior of Argentina. With low levels of education and skills, they mostly entered the informal sector of the labour market, with working conditions and wages that were lower than those of the native population (locallyborn citizens or long-time residents). Consequently, they were more vulnerable than the native population

\footnotetext{
$\square$ The authors wish to express their thanks for the valuable comments of an anonymous referee.

1 In this paper, "migrants from neighbouring countries" refers to foreigners from Chile, Paraguay, Uruguay, Bolivia, Brazil and also, in the 1990s, Peru, while "internal migrants" means those coming from Argentine provinces in the interior of the country. The provinces from which such migrants came were mainly Santiago del Estero, Corrientes, Chaco, Entre Ríos, Tucumán, Salta and Jujuy. Table A.1 of the Appendix shows the relative proportions of internal migrants and those from neighbouring countries, by province or country of origin.

${ }^{2}$ The migration rate went down from 2.3 per thousand in the 19701975 period to -1.6 per thousand in 1975-1980 (CELADE, 1998), and there was also a decline in the proportions of migrants from other provinces (from $8 \%$ to $6 \%$ ) and from neighbouring countries (from $0.9 \%$ to $0.5 \%$ ) in the total population (INDEC, 1980).
}

to cyclical swings in the economy and employment. ${ }^{3}$

In the 1990s, however, the behaviour of internal and cross-border migrants to Greater Buenos Aires took on different features from those prevailing in the previous period. During the short period from 1991 to 1993 , the growth rates of the product, labour supply and employment all coincided, and in those years the recovery of the economy and the increase in the demand for labour became a factor of attraction for internal migrants, while the overvaluation and stability of the local currency also attracted migrants from neighbouring countries. After the crisis in 1995 and during the period of expansion between 1996 and 1999, however, there was a decline in the demand for labour in the most traditional sectors in which those migrants sought work, and this affected the level of internal migrations. Migrations from neighbouring countries behaved differently, however: the fixed exchange rate lasted until the end of 2001 and served as an incentive for migration from other countries of the region.

In addition to this reduction in internal migration flows and the maintenance of those from neighbouring countries, some differences also began to emerge in the composition and employment status of recent migrants in both groups. ${ }^{4}$ Firstly, whereas in the 1970 s and 1980s both groups had similar levels. of education, in the 1990 s the cross-border migrants -especially the women- had higher levels of education than those of the internal migrants. Secondly, the labour trajectories of the two groups started to draw apart. The severe crisis in 1995 caused a contraction in labour demand in the construction, domestic service and manufacturing sectors, which became net expul sors of labour. ${ }^{5}$ This gave rise to an increase in open unemployment in both groups of recent migrants, but

\footnotetext{
3 Between 1978 and 1982, for example, unemployment in the metropolitan area of Buenos Aires - "Greater Buenos Aires" - affected migrants more than natives (Cortés, 1985).

4 The analysis of the behaviour of recent cross-border and internal migrants is limited to those migrants arriving in the area in the last ten years, according to the respective measurements of the Permanent Household Surveys. The source of the information is described in the Appendix.

5 The nationwide unemployment rate in construction rose from $14 \%$ in 1993 to $31 \%$ in 1995 , subsequently never falling below $23 \%$
} 
among the internal migrants there was also an increase in the proportion of inactive persons - those in the "not working nor looking for work" category - which was probably a factor in the slackening in migration flows and - this is speculation, since there are no data that prove or disprove it - an increase in the rate of departure from the metropolitan area.

After the brief period of economic expansion which ended in 1994, and as from the 1995 recession, the decline in the proportion of internal migrants in the area in question would appear to indicate that open unemployment acted as a factor that discouraged internal migration to the area. In contrast, the overvaluation of the local currency exchange rate continued to attract migrants from neighbouring countries (including Peru). The decline in employment in the branches which traditionally employed migrant labour was a factor in the reduction of the proportion of internal migrants, while there was an increase in the relative proportion of cross-border migrants, who finally lasted longer in these jobs. This situation of high unemployment and relative abundance of cross-border migrant labour favoured the spread of precarious working conditions in this segment; recent cross-border migrant workers formed a segment marked by low-quality working conditions: lack of social protection, long hours and low wages. The internal migrants, for their part, without a trade or engaged in only casual employment, with few possibilities of improving their situation in the near future, swelled the hard core of unemployed likely to sink into structural poverty.

\section{II}

\section{Migrations and the labour market in Argentina}

\section{The debate in the 1980s and 1990s}

The studies carried out between the late 1970s and the 1990s all identify internal and cross-border migrants as one of the segments most vulnerable to economic swings. They do not coincide, however, in their interpretation of the characteristics of the labour market or the role of migrants in it. According to one line of research, up to the 1980s Argentina suffered from a shortage of unskilled labour and that the rate of economic growth was sufficient to ensure that the migrants were absorbed and integrated into the urban labour market (Mármora, 1977). Other interpretations more in line with the thinking of Lewis, however (Marshall, 1977), argued that the local labour market was marked by sluggish growth in the demand for unskilled labour and the existence of a segment of surplus workers. According to this argument, the demand for migrants suffered from the same sluggishness: migrants were not required by the host economy, since they were the result of processes of expulsion from the

(Ministry of Labour, www.observatorio.net). In Greater Buenos Aires, the unemployment rate in domestic service fluctuated around $17 \%$ from 1995 on, according to data from the Permanent Household Survey carried out by the National Institute of Statistics and Censuses (INDEC). economies of origin and therefore entered occupations outside the formal labour market. According to this view, the growth rate of manufacturing and the urbanization process played a central role in the variations in the volume of migrations as well as in the way migrants entered the labour force in the metropolitan area. Some authors (Marshall, 1977; Marshall and Orlanski, 1983) described from this perspective how in the 1960s, as a result of technological modernization, the concentrated segment of industry had ceased to require unskilled labour, so that migrants had to work in construction and small-scale industry.

In the late 1980s, studies on poverty included the migration dimension; thus, one study on the links between migration and poverty found evidence that in Greater Buenos Aires, in 1988, the incidence of poverty among recent migrants was higher among cross-border migrants than among internal migrants (Maguid, 1990 , p. 25). It was also argued in that study that the educational level of recent cross-border migrants was lower than that of internal migrants: findings which differ from those given in the present study. ${ }^{6}$

\footnotetext{
6 The study by Maguid (1990) was based on 1990 data from the "Investigación sobre Pobreza en Argentina" (IPA) project, but if the Permanent Household Surveys are used as the data source, in 1980 there was no difference between the educational levels of recent cross-border and internal migrants.
} 
The debate on the enforcement of population laws and regulations during the 1990s -both with regard to the amnesty and bilateral agreements and the decrees on the expulsion of illegal aliens- revived interest in the relation between migrations and the labour market. The public debate revolved around the role of cross-border migrations in the increased unemployment rate, and there were heated discussions about the extent to which cross-border migrants were competing with local residents for jobs: in other words, about how far they could be "blamed" for the high rate of unemployment.

There were two particularly outstanding subjects of discussion: the rate of migrations from neighbouring countries in the 1990s and the way these migrants entered the labour force. With regard to the first of these questions, Lattes (1997) questioned the demographic projections predicting zero migration balances by the year 2015, since according to his estimates there had been no interruption in the volume of crossborder migrations. ${ }^{7} \mathrm{He}$ also argued that both the active population and the rates of participation in economic activity increased during the 1990s as a result of migrations, natural growth and other factors such as the greater propensity of women to participate in the labour force. Maguid (2001), in contrast, minimized the role of the low fixed exchange rate as an incentive for cross-border migration and claimed that in the first half of the 1990s the contraction in the demand for labour of itself reduced cross-border migration.

With regard to the way migrants entered the labour force, a by no means negligible proportion of local authors put forward the hypothesis that the crossborder and internal segments of recent migration flows did not compete for jobs: on the contrary, there was rather some degree of "complementation" or "absence of competition" between them (Mármora, 1994). This view was maintained, for example, by authors such as Maguid (1995) and Benencia and Gazotti (1995), who claimed that the contribution of cross-border migration to open unemployment in the metropolitan area has been negligible. Montoya and Perticará (1995) came to the same conclusion, although they did wonder how far this could be extended to all internal migrants, since in their view internal migrants from the relatively less developed provinces might have

\footnotetext{
7 In Lattes (1997) the migration flows were estimated by using data for 1991-1996 from the Permanent Household Surveys, brought into line with those from the 1991 Population and Housing Census.
}

affected the level of unemployment.

Marshall (2000), in contrast, argued that there were grounds for maintaining that cross-border migrants did compete -marginally- with other recent migrants for the same kind of jobs. Revising the views they expressed in 1995, in subsequent studies Benencia (2000) and Maguid (2001) accept the possibility that there may have been some degree of competition between recent cross-border migrants and internal migrants in the metropolitan area. Maguid (2001) considers that the impact of migrations from neighbouring countries on the local labour market depended on the level of economic activity. Maintaining his view that there was a shortage of unskilled labour in the urban labour market in Argentina, he argues that in periods when there was a sustained demand for labour, such as during the import substitution industrialization era, native citizens rejected low-quality jobs. In his revised view, he holds that in the 1990s the decline in the manufacturing product, plus other changes, reduced the level of demand for labour, thereby causing native citizens to be "willing to work in jobs that they previously rejected" (Maguid, 2001, p.67). He consequently accepts that the new recessionary context may have led to competition between migrants and native citizens in the construction and domestic service sectors and may also have led to a reversal of cross-border migration flows. He accepts, however, that "there is no reliable information ..... that shows whether immigration has declined or there has been a process of substitution between new migrants and older ones returning to their countries of origin" (Maguid, 2001, p.65). From the standpoint taken in the present article, this analysis attaches excessive importance to voluntary decisions by the native and internal migrant population not to compete with cross-border migrants, while failing to give due weight to the role of the demand for labour in the distribution of jobs.

In the present article, it is considered that in the 1990s the flow of cross-border migrants continued, ${ }^{8}$ and that during the expansionary phases of the economic cycle the employment of cross-border migrants grew more rapidly than that of internal migrants, pre-

\footnotetext{
8 Between 1993 and 2001 the recent migrant population (with ten or fewer years of residence) in the Buenos Aires metropolitan area went down from 141,093 to 105,017 (25\%), while the number of cross-border migrants increased from 230,504 to 265,852 (15\%), according to the Permanent Household Surveys. The employed population of internal migrants went down from 1,061,388 to $933,027(12 \%)$.
} 
cisely in the same branches of activity in which the latter were mainly concentrated. In contrast, although during recessions there were dismissals of both types of migrants from the construction and domestic service sectors, when the economy recovered only the employment of cross-border migrants grew in these two sectors; not that of internal migrants. ${ }^{9}$

The differences in the levels of qualifications, which favoured the cross-border migrants, and the acceptance by the latter of low wages and long hours, made it more attractive to hire this type of migrant. As from 1995, there was a decline in internal migrations to the area; the high levels of unemployment prevailing there probably caused migrations to other urban centres, open unemployment, a feeling of discouragement and sporadic participation in the labour force: i.e., various different aspects of a growing process of abandonment of the world of work.

This suggests that there was a process in which workers in the construction and domestic service sectors who were recent internal migrants were replaced by recent cross-border migrants. In addition to the processes of exclusion from the labour market there were other problems which, together, affected recent internal migrants more severely. This group would appear to have been concealing, in the course of the last ten years, a sector not recorded in the statistics and hidden behind a situation of inactivity, which could be called the "relatively excluded" sector. Although the information currently available does not provide sufficient evidence to confirm this tendency, this matter warrants more investigation in the future.

\section{The regulatory framework}

The Buenos Aires metropolitan area was a centre of attraction for internal and international migrations from the 1930s up to the mid-1970s. The slackening in migrations increased the proportion of native citizens and reduced the weight of migrants in the population

\footnotetext{
9 After the drop in the proportion of recent cross-border and internal migrants employed in the construction sector between 1994 and 1995, in 1996 the proportion of internal migrants continued to fall, whereas the proportion of cross-border migrants increased. Thus, the latter accounted for $40 \%$ of the total in $1995,53 \%$ in $1996,57 \%$ in 1997 and $58 \%$ in 1998 (calculations by the authors on the basis of data from the Permanent Household Surveys).
}

of this area. ${ }^{10}$ Cross-border migration nevertheless continued to be concentrated there, however, ${ }^{11}$ and this pattern of geographical distribution continued in the 1990s: Greater Buenos Aires accounted for $70 \%$ of the cross-border migrants residing in urban areas, $75 \%$ of the cross-border migrants with jobs who arrived over the last ten years, and $78 \%$ of those who arrived during the last five years. ${ }^{12}$

During the years of military rule (1976-1983), the legislation on migrations was predominantly restrictive. In 1981 the General Law on Migrations and the Promotion of Immigration was adopted, with the aim of exclusively promoting "the immigration of foreigners whose cultural characteristics permit their appropriate integration" and discouraging immigration from neighbouring countries. ${ }^{13}$ An important point in this law was the imposition of restrictions on the employment of transient and temporary residents: both they and the employers who opted to hire them had to comply with a number of requirements. From this point on, and even after the beginning of the democratic phase, the legislation did not follow a single line: while some decrees restricted migration flows, some amnesties were also decreed, as for example that in 1984. In 1985 (decree 828/85), restrictions were once more imposed on migration - further intensified in 1987 with the regulation of entry permits, which made it difficult to take out legal residence - and stricter controls were applied to migration, although in the 1990s more permissive bilateral agreements on the entry of nationals of neighbouring countries. The regulatory framework did not play an ongoing dissuasive role with regard to the decision to migrate or to employ migrants, however, since effective controls were not always put into effect to enforce compliance with the restrictive legislation. This lack of controls made it possible to use cross-border migrant labour, which in any case took place outside the law.

\footnotetext{
${ }^{10}$ In the metropolitan area, between the 1980 and 1991 censuses, the proportion of non-neighbouring international migrants in the population went down from $4.4 \%$ to $2.5 \%$, while that of internal migrants went down from $22.6 \%$ to $19.5 \%$. The proportion of nonmigrants, however, rose from $70.6 \%$ to $75.5 \%$ (INDEC, 1991).

${ }^{11}$ In the City of Buenos Aires, between 1980 and 1991, the proportion of cross-border migrants increased from $2.9 \%$ to $3.9 \%$ and remained unchanged in the 19 sections covering the Buenos Aires conurbation (INDEC, 1991).

${ }^{12}$ Estimates by the authors, based on data from the Permanent Household Surveys.

${ }^{13}$ Text of the General Law on Migrations and the Promotion of Immigration, No. 22439/1981. See CELS (2000) and Novick (2001).
} 
This situation of illegality was a contributory factor in causing workers from neighbouring countries to accept precarious working conditions (lack of pensions, heavier workloads, lack of access to trade union representation, etc.), and although in strictly legal terms there were no obstacles to them bringing labourrelated legal proceedings, their nationality may well have deterred workers from initiating such proceedings. ${ }^{14}$ These difficulties in gaining access to justice, together with the rising unemployment, created suitable conditions for the spread of the use of cross-bor- der labour under increasingly substandard conditions. The increase in non-labour production costs (energy, communications, transport) encouraged firms to use strategies aimed at reducing the labour component of costs, as for example by hiring migrant workers, and the hiring of cross-border migrants made more sense than hiring internal migrants, because on the one hand their skills were in no way inferior to those of the latter, and on the other hand they formed a labour force which was very easily disciplined.

\section{III}

\section{Internal and cross-border migrants in the 1990s}

\section{Activity, employment and unemployment}

Between 1993 and 2000, the variations in cross-border migration flows, as a proportion of both the total and the active population, were positively linked with the evolution of overall GDP and, in particular, that of the sectors in which recent cross-border migrants were concentrated. In the case of internal migrants, in contrast, the link between migration and the product was negative (table 1). The demand for labour in the economic sectors where migrants were typically employed, which was more clearly directed towards cross-border migrants, was one of the factors which led to changes in the composition of both the total and the active population. The weight of the migratory groups of different origins in the population changed during those years: the proportion of internal migrants went down slightly, but that of cross-border migrants showed an upward trend (table 2). The economically active population also changed in the same direction, since the proportion of internal migrants went down, while that of cross-border migrants increased slightly (table 3).

The direction of these changes is also reflected in the different growth rates of the economically active population, the employed population, and the unemployed. The percentage of economically active internal migrants ceased to grow, while the proportion of employed persons fell in this segment and the percentage of unemployed rose. In contrast, the percentages of economically active persons, employed persons and unemployed all rose among the cross-border migrants. The factor marking the greatest difference between the two types of migrants was that employment only rose among the cross-border migrants (table 4 and figure A.1 of the appendix).

A breakdown of the variations in the size of the sub-populations of employed and unemployed (table 5) shows that between 1993 and 1995 cross-border migrants played a more important role than internal migrants and even than native local citizens in the variation in the level of employment. If we analyze the other periods we see that although the most important contribution was that of non-migrants, the contribution of cross-border migrants to employment and the economically active population was greater than that of internal migrants. In all periods the latter contributed more than the others to urban unemployment. Table 4 suggests that in periods of recession recent internal and cross-border migrants lost their jobs more frequently than native local citizens, with the loss being even more marked in the case of recent internal migrants. The latter class of migrants had no effect on the levels of employment or activity, but they did help to explain the variations in unemployment in different periods.

\footnotetext{
${ }^{14}$ Interview with Dr. Pedro I. Galin, consultant on labour matters, Buenos Aires, 4 October 2002.
} 
TABLE 1

Argentina: Coefficients of correlation between the gross domestic product and migration

\begin{tabular}{|c|c|c|c|c|c|}
\hline $\begin{array}{l}\text { 1993-2000 } \\
\text { Population groups by migratory origin }\end{array}$ & GDP & $\begin{array}{l}\text { Manufacturing } \\
\text { GDP }\end{array}$ & $\begin{array}{l}\text { Construction } \\
\text { GDP }^{\mathrm{a}}\end{array}$ & $\begin{array}{l}\text { Services } \\
\text { GDP }^{b}\end{array}$ & $\begin{array}{l}\text { Commerce } \\
\text { GDP }^{\mathrm{c}}\end{array}$ \\
\hline Internal migrants/total population & -0.13 & -0.10 & -0.36 & -0.16 & -0.5 \\
\hline Recent internal migrants/total population & -0.53 & -0.50 & -0.63 & -0.55 & -0.42 \\
\hline Cross-border migrants/total population & 0.90 & 0.71 & 0.69 & 0.93 & 0.67 \\
\hline Recent cross-border migrants/total population & 0.49 & 0.26 & 0.68 & 0.60 & 0.19 \\
\hline Internal migrants/economically active population & 0.06 & 0.13 & -0.16 & -0.06 & 0.19 \\
\hline Recent internal migrants/economically active population & -0.60 & -0.54 & -0.63 & -0.62 & -0.45 \\
\hline Cross-border migrants/economically active population & 0.82 & 0.61 & 0.59 & 0.89 & 0.55 \\
\hline Recent cross-border migrants/economically active population & 0.34 & 0.05 & 0.19 & 0.47 & -0.03 \\
\hline
\end{tabular}

Source: Prepared by the authors on the basis of data in absolute values on the gross domestic product, at current prices, provided by the Ministry of the Economy (base year 1993), and data in absolute values from the October figures of the Permanent Household Census for Greater Buenos Aires.

a In the case of the construction sector, the coefficients of correlation were calculated for the 1993-1999 period in order to avoid the skew caused by the marked fall in activity in this sector in 2000 . Whereas the tequila crisis caused a fall of $6 \%$ in the construction GDP in $1994-$ 1995, the recession between 1999 and 2000 caused a contraction of $-13 \%$.

b Includes social, community and personal services; excludes education, health and public administration.

c Wholesale and retail trade and repairs.

TABLE 2

Greater Buenos Aires: Composition of population by migratory status (Percentages)

\begin{tabular}{|c|c|c|c|c|c|}
\hline Year & $\begin{array}{c}\text { Total } \\
\text { population }\end{array}$ & $\begin{array}{l}\text { Total non- } \\
\text { migrant } \\
\text { population }\end{array}$ & $\begin{array}{l}\text { Total internal } \\
\text { migrant } \\
\text { population }\end{array}$ & $\begin{array}{l}\text { Total cross- } \\
\text { border migrant } \\
\text { population }\end{array}$ & $\begin{array}{l}\text { Total international } \\
\text { migrant population } \\
\text { of other origins }\end{array}$ \\
\hline 1993 & 100 & 73.4 & 18.1 & 3.8 & 4.7 \\
\hline 1994 & 100 & 72.9 & 19.1 & 3.6 & 4.4 \\
\hline 1995 & 100 & 72.8 & 18.8 & 4.0 & 4.4 \\
\hline 1996 & 100 & 72.5 & 19.0 & 4.2 & 4.2 \\
\hline 1997 & 100 & 73.4 & 18.2 & 4.5 & 3.9 \\
\hline 1998 & 100 & 74.7 & 17.5 & 4.6 & 3.2 \\
\hline 1999 & 100 & 75.3 & 16.9 & 4.7 & 3.1 \\
\hline 2000 & 100 & 76.0 & 16.8 & 4.3 & 2.9 \\
\hline 2001 & 100 & 75.8 & 17.0 & 4.6 & 2.6 \\
\hline
\end{tabular}

Source: Permanent Household Survey.

TABLE 3

Greater Buenos Aires: Composition of economically active population by migratory status, 1993-2001

(Percentages)

\begin{tabular}{|c|c|c|c|c|c|}
\hline Year & $\begin{array}{c}\text { Total } \\
\text { economically active } \\
\text { population (EAP) }\end{array}$ & $\begin{array}{c}\text { Non-migrant } \\
\text { EAP }\end{array}$ & $\begin{array}{l}\text { Internal } \\
\text { migrant } \\
\text { EAP }\end{array}$ & $\begin{array}{l}\text { Cross-border } \\
\text { migrant } \\
\text { EAP }\end{array}$ & $\begin{array}{c}\text { International } \\
\text { migrant EAP } \\
\text { from other origins }\end{array}$ \\
\hline 1993 & 100 & 67.1 & 24.0 & 5.4 & 3.5 \\
\hline 1994 & 100 & 66.8 & 25.0 & 5.0 & 3.1 \\
\hline 1995 & 100 & 65.8 & 24.9 & 5.8 & 3.5 \\
\hline 1996 & 100 & 66.6 & 24.5 & 5.8 & 3.1 \\
\hline 1997 & 100 & 67.4 & 23.4 & 6.2 & 3.0 \\
\hline 1998 & 100 & 68.5 & 22.8 & 6.2 & 2.5 \\
\hline 1999 & 100 & 69.5 & 21.6 & 6.5 & 2.4 \\
\hline 2000 & 100 & 70.8 & 21.0 & 6.1 & 2.2 \\
\hline 2001 & 100 & 71.1 & 21.0 & 6.2 & 1.6 \\
\hline
\end{tabular}

Source: Permanent Household Survey, figures for October, Greater Buenos Aires. 
Greater Buenos Aires: Annual average rates of variation in the total, active, employed and unemployed population, 1993-2001

(Percentages)

\begin{tabular}{lccccc}
\hline Population & $\begin{array}{c}\text { Non- } \\
\text { migrants }\end{array}$ & $\begin{array}{c}\text { Internal } \\
\text { migrants }\end{array}$ & $\begin{array}{c}\text { Cross-border } \\
\text { migrants }\end{array}$ & $\begin{array}{c}\text { Other } \\
\text { international migrants }\end{array}$ & Total \\
\hline $\begin{array}{l}\text { Total population } \\
\begin{array}{l}\text { Economically active } \\
\text { population }\end{array}\end{array}$ & 1.93 & 0.75 & 4.00 & -5.76 & 1.52 \\
$\begin{array}{l}\text { Employed } \\
\text { population }\end{array}$ & 2.52 & 0.10 & 3.47 & -7.57 & 1.75 \\
$\begin{array}{l}\text { Unemployed } \\
\text { population }\end{array}$ & 1.23 & -1.60 & 1.80 & -8.69 & 0.32 \\
\hline
\end{tabular}

Source: Permanent Household Survey, figures for October, Greater Buenos Aires.

TABLE 5

Greater Buenos Aires: Breakdown of increases in sub-populations, by migratory status, in selected periods

(Percentages)

\begin{tabular}{|c|c|c|c|c|c|}
\hline Period & $\begin{array}{l}\text { Non- } \\
\text { migrants }\end{array}$ & $\begin{array}{l}\text { Internal } \\
\text { migrants }\end{array}$ & $\begin{array}{l}\text { Cross-border } \\
\text { migrants }\end{array}$ & $\begin{array}{l}\text { Other } \\
\text { international migrants }\end{array}$ & Total $^{\mathrm{a}}$ \\
\hline \multicolumn{6}{|c|}{ Total population } \\
\hline $1995-1993$ & 45 & 44 & 11 & & 100 \\
\hline $1997-1993$ & 63 & 18 & 19 & & 100 \\
\hline 2001-1993 & 83 & 8 & 10 & & 100 \\
\hline \multicolumn{6}{|c|}{ Economically active population } \\
\hline $1995-1993$ & 37 & 45 & 14 & 3 & 100 \\
\hline $1997-1993$ & 69 & 15 & 15 & & 100 \\
\hline 2001-1993 & 89 & 1 & 10 & & 100 \\
\hline \multicolumn{6}{|c|}{ Employed population } \\
\hline $1995-1993$ & & & 100 & & 100 \\
\hline $1997-1993$ & 68 & & 32 & & 100 \\
\hline 2001-1993 & 89 & & 11 & & 100 \\
\hline \multicolumn{6}{|c|}{ Unemployed population } \\
\hline $1995-1993$ & 64 & 26 & 7 & 3 & 100 \\
\hline $1997-1993$ & 65 & 25 & 5 & 4 & 100 \\
\hline 2001-1993 & 69 & 23 & 8 & 1 & 100 \\
\hline
\end{tabular}

Source: Permanent Household Survey, figures for October, Greater Buenos Aires.

a The totals do not include cases in which the migratory status was not reported.

In the 1990s, there was an expansion in the rates of activity and of unemployment in the total population of Greater Buenos Aires. In order to estimate the extent to which variations in the volume of the labour supply affected the rates of unemployment in the different subpopulations, we carried out the following exercise. We calculated the value reached by the unemployment rate between 1993 and 2000 with a constant activity rate and then compared the result with the unemployment rate actually observed (real unemployment rate); the resulting coefficient was taken as a proxy for the net effect of the demand for labour, which indicates the portion of unemployment caused by the elimination of jobs. As may be seen from table 6 , the net effect of the demand for labour differs between population groups according to sex and migratory origin.

For the labour force as a whole, the variations in the rate of participation had rather more weight than the elimination of jobs in the increase in unemployment (3.1 percentage points and 2.2 points, respectively). The groups of different migratory origin behaved differently, however.

i) Non-migrants. The general tendency was more marked in the case of women than of men. Among women, it was the expansion in the rate of participation which affected the unemployment rate, whereas among men, both factors contributed equally to the increase in unemployment. 
ii) Internal migrants. Men were marked by a fall in the activity rate: a factor which helped to soften the increase that would otherwise have been registered by the unemployment rate as a result of elimination of jobs. Thus, in the case of men, if this fall in the activity rate had not taken place the unemployment rate of this group would have risen by more than 12 percentage points. In contrast, the increase in unemployment among female internal migrants was due in equal extents to the elimination of jobs and the increase in the labour supply.

iii) Cross-border migrants. Female cross-border migrants increased their participation rate, but the increase in the employment rate was even greater, which was why unemployment went down among them. In the case of male cross-border migrants, the elimination of jobs was the most decisive factor in the increase in unemployment.

TABLE 6

Greater Buenos Aires: Changes in unemployment, by migratory status

(Percentages)

\begin{tabular}{|c|c|c|c|c|c|}
\hline $\begin{array}{l}\text { Population, by } \\
\text { migratory status rates }\end{array}$ & $\begin{array}{l}\text { Unemployment } \\
\text { rate, } 1993\end{array}$ & $\begin{array}{l}\text { Unemployment } \\
\text { rate, } 2000\end{array}$ & $\begin{array}{l}\text { Employment } \\
\text { effect }\end{array}$ & $\begin{array}{l}\text { Activity } \\
\text { effect }\end{array}$ & $\begin{array}{l}\text { Difference between } 1993 \\
\text { and } 2000 \text { unemployment }\end{array}$ \\
\hline Total active population & 9.6 & 14.9 & 2.2 & 3.1 & 5.3 \\
\hline Non-migrants & 10.2 & 14.8 & -0.3 & 4.9 & 4.6 \\
\hline Men & 8.0 & 12.6 & 2.5 & 2.0 & 4.6 \\
\hline Women & 13.7 & 18.0 & -5.4 & 9.7 & 4.3 \\
\hline Internal migrants & 8.3 & 16.0 & 9.5 & -1.7 & 7.8 \\
\hline Men & 7.4 & 14.7 & 12.5 & -5.3 & 7.3 \\
\hline Women & 9.6 & 17.9 & 4.2 & 4.1 & 8.4 \\
\hline Cross-border migrants & 12.1 & 14.4 & 0.5 & 1.9 & 2.3 \\
\hline Men & 11.7 & 17.6 & 5.8 & 0.1 & 5.9 \\
\hline Women & 12.6 & 10.3 & -4.7 & 2.3 & -2.4 \\
\hline
\end{tabular}

Source: Permanent Household Survey, October figures, Greater Buenos Aires.

TABLE 7

Greater Buenos Aires: Recalculation of activity and unemployment rates (Percentages)

\begin{tabular}{|c|c|c|c|c|c|}
\hline \multicolumn{6}{|c|}{ A. Activity rate } \\
\hline & Non migrants & Internal migrants & Cross-border migrants & Total & $\begin{array}{c}\text { Percentage difference } \\
\text { with respect to observed rate }\end{array}$ \\
\hline$\overline{1993}$ & 39.5 & 57.3 & 62.2 & 43.3 & \\
\hline 1996 & 41.1 & 57.7 & 61.2 & 44.9 & \\
\hline 2001 & 41.4 & 54.4 & 59.7 & 44.1 & \\
\hline $1996^{\mathrm{a}}$ & & & & 44.8 & -0.06 \\
\hline $1996^{\mathrm{b}}$ & & & & 44.6 & -0.22 \\
\hline $2001^{\mathrm{a}}$ & & & & 44.0 & -0.11 \\
\hline $2001^{b}$ & & & & 44.0 & -0.11 \\
\hline
\end{tabular}

\begin{tabular}{|c|c|c|c|c|c|}
\hline \multicolumn{6}{|c|}{ B. Unemployment rate } \\
\hline & Non migrants & Internal migrants & Cross-border migrants & Total & $\begin{array}{c}\text { Percentage difference } \\
\text { with respect to observed rate } 1993\end{array}$ \\
\hline 1993 & 10.2 & 8.3 & 12.1 & 9.6 & \\
\hline 1996 & 19.1 & 19.3 & 19.3 & 18.8 & \\
\hline 2001 & 18.8 & 20.0 & 22.8 & 19.3 & \\
\hline $1996^{\mathrm{c}}$ & & & & 18.5 & -0.4 \\
\hline $1996^{\mathrm{d}}$ & & & & 17.6 & -1.2 \\
\hline $2001^{\mathrm{c}}$ & & & & 18.7 & -0.6 \\
\hline $2001^{\mathrm{d}}$ & & & & 17.9 & -1.4 \\
\hline
\end{tabular}

Source: Permanent Household Survey, October figures, Greater Buenos Aires.

a New rate, assuming there were no new cross-border migrants since 1993. The total number and number of active cross-border migrants would be the same as in 1993 .

b New rate, without recent cross-border migrants.

c New rate, assuming that unemployment among cross-border migrants was the same as in 1993.

d New rate, without unemployed and employed recent cross-border migrants, with redistribution of jobs. 
Table 7 gives an estimate of the effect of crossborder migration on overall activity and unemployment rates. Both rates were recalculated according to the assumption that there had been no increase in cross-border migration since 1993, and even that there had been no entry of migrants at all in the last ten years. The differences registered are only slight. Thus, although the sign is of the expected type (reduction in both rates), because of the relatively minor weight of cross-border migrants in relation to the rest of the groups, the proportion by which those rates went down is only marginal: the activity rate goes down by less than one percentage point, while the open unemployment rate goes down by a little more than that value (in both cases, according to the most restrictive assumption).

An estimate was also made of the impact of migrations on the tendencies that might be expected in the rates of activity, employment and unemployment according to the behaviour registered during the 1990s. Through ordinary least squares linear regression analysis, the proportions of internal and crossborder migrants in the labour supply and the employed population were taken as independent variables, and the above-mentioned rates of activity, employment and unemployment were taken as dependent variables (tables A.1, A.2 and A.3 of the appendix). ${ }^{15}$ The regression analysis showed that cross-border migrations affected almost exclusively unskilled young people, but not the other age groups or the groups with higher levels of education (for example, the employment rate of persons under 30 with incomplete secondary education goes down as a result of the presence of recent cross-border migrants in the labour supply).

To sum up, the tables indicate that there was a halt in internal migrations but not in those from neighbouring countries, and this affected the relative weights of the two groups in the active population. The volume of migrants was not enough, however, to affect the rates of activity, employment or unemployment. In addition, there was an increase in the economic activity of non-migrant female natives, female internal migrants, and female migrants from neighbouring countries, but the losses of jobs were concentrated solely among female internal migrants. In the case of men, there was a decline in the proportion of

\footnotetext{
${ }^{15}$ In order to have enough observations, the May and October figures of the Permanent Household Survey for the period from October 1993 to May 2002 were used.
}

employed persons in all three groups, but the biggest decline was among male internal migrants.

\section{Occupational breakdown}

In order to make a breakdown of the occupational sectors in which migrants work we formed a data pool by adding together the October figures from the Permanent Household Surveys for 1993, 1995, 1997, 1999 and 2001. This made it possible to increase the number of cases in order to permit their analysis, assuming that the groups maintained common features throughout the period. ${ }^{16}$

In the 1990s, the patterns of sectoral occupation of employed migrants - both cross-border and internal settling in the Greater Buenos Aires area had not changed substantially from the previously prevailing trends. Migrants in general (regardless of when they arrived) continued to be concentrated in construction, domestic service and the textile sector, although those from neighbouring countries had greater weight in that decade. Thus, these three sectors accounted for $46.4 \%$ of recent cross-border migrants and $32.3 \%$ of recent internal migrants; if their date of arrival is not taken into account, there was a higher relative proportion of cross-border than of internal migrants in those activities: $57.6 \%$ and $27 \%$, respectively.

During the economic growth stage - up to 1995 cross-border migrants continued to be in demand due to the growth of the typical urban economic sectors, but this was not so in the case of internal migrants; in the stage of recession, however, when construction and manufacturing became net expellers of labour, both groups of migrants were affected by the decline in the demand for labour.

Cross-border migrants occupied jobs previously occupied by internal migrants, in unregistered wageearning jobs in construction and in domestic service, and to a lesser extent in the garment and leather and footwear industries, while internal migrants resorted more often to own-account activities.

\footnotetext{
${ }^{16}$ See the second paragraph of the appendix.
} 
TABLE 8

Greater Buenos Aires: Composition of recent migrants employed in the construction sector, by migratory origin, 1993 to 2001 (Percentages)

\begin{tabular}{lccc}
\hline Year & $\begin{array}{c}\text { Recent } \\
\text { internal } \\
\text { migrants }\end{array}$ & $\begin{array}{c}\text { Recent } \\
\text { cross-border } \\
\text { migrants }\end{array}$ & Total \\
\hline 1993 & 58.5 & 41.5 & 100 \\
1995 & 45.7 & 54.3 & 100 \\
1997 & 33.1 & 66.9 & 100 \\
1999 & 6.9 & 93.1 & 100 \\
2001 & 19.7 & 80.3 & 100 \\
\hline
\end{tabular}

Source: Prepared by the authors on the basis of the October figures of the Permanent Household Census.

TABLE 9

Greater Buenos Aires: Composition of recent migrants employed in domestic service, by migratory origin, 1993 to 2001 (Percentages)

\begin{tabular}{lccc}
\hline Year & $\begin{array}{c}\text { Recent } \\
\text { internal } \\
\text { migrants }\end{array}$ & $\begin{array}{c}\text { Recent } \\
\text { cross-border } \\
\text { migrants }\end{array}$ & Total \\
\hline 1993 & 45 & 55 & 100 \\
1995 & 41.5 & 58.5 & 100 \\
1997 & 21 & 79 & 100 \\
1999 & 29.1 & 70.9 & 100 \\
2001 & 8.9 & 91.1 & 100 \\
\hline
\end{tabular}

Source: Prepared by the authors on the basis of the October figures of the Permanent Household Census.

TABLE 10

Greater Buenos Aires: Breakdown of recent internal and cross-border migrants, by sector of activity (Percentages)

\begin{tabular}{llrrr}
\hline Sex & Sector & \multicolumn{2}{c}{ Migrants } & Total \\
\cline { 3 - 4 } & & Internal & Cross-border & \\
\hline Men & Manufacturing & 27.3 & 28.5 & 27.8 \\
& Construction & 10.7 & 36.4 & 19.2 \\
& Others & 62.0 & 35.1 & 53.0 \\
& Total & 100.0 & 100.0 & 100.0 \\
\hline \multirow{2}{*}{ Women } & Manufacturing & 10.8 & 12.0 & 11.3 \\
& Domestic service & 40.4 & 63.8 & 50.7 \\
& Others & 48.8 & 24.2 & 38.0 \\
& Total & 100.0 & 100.0 & 100.0 \\
\hline
\end{tabular}

Source: Pooled data from the Permanent Household Survey (October figures) for Greater Buenos Aires, for 1993, 1995, 1997, 1999 and 2001
Among men, 36.4\% of recent cross-border migrants and $10.7 \%$ of recent internal migrants were employed in construction, while among women, $63.8 \%$ of cross-border migrants worked in domestic service, compared with $40.4 \%$ of female internal migrants. ${ }^{17}$

Although there is a historical continuity in the proportion of wage-earners in the two groups, it is clear that in the 1990s the wage-earning jobs in the typical economic sectors of construction and domestic service went more to the cross-border migrants $(77 \%$ and $51 \%$, respectively). In the case of women in domestic service, the same tendency is observed, with proportions of (female) wage-earners of $84 \%$ and $76 \%$.

The incidence of precarious employment - jobs not registered with the authorities - was higher among the cross-border migrants: only $26 \%$ of cross-border wage-earners worked in jobs protected by social security, $60.2 \%$ were not registered, and the remainder enjoyed some partial benefits; among the internal migrants, in contrast, the standards of labour protection, although low, were somewhat higher than those of the cross-border migrants (table 13).

TABLE 11

Greater Buenos Aires: Composition of recent migrant wage-earners, by migratory origin, 1993 and 2001

(Percentages)

\begin{tabular}{lccc}
\hline Wage-earners & Internal & Cross-border & Total \\
\hline 1993 & 64.6 & 35.4 & 100 \\
2001 & 61.6 & 38.4 & 100
\end{tabular}

Source: Prepared by the authors on the basis of data from the Permanent Household Survey (October figures) for Greater Buenos Aires.

\footnotetext{
${ }^{17}$ According to the pooled data, in the 1993-2001 period the proportion of recent cross-border migrants among the total employed was of the order of $2.4 \%$, while the proportion of recent internal migrants was around $2.6 \%$. In view of the historical over-representation of these groups in construction and domestic service, a comparison by sectors is in order. Thus, $45 \%$ of those employed in domestic service were internal migrants $13 \%$ were cross-border migrants, and $41 \%$ were non-migrants, but when the comparison is restricted to the recent migrants group (up to ten years), the proportion of cross-border migrants rises to $48 \%$ and that of internal migrants goes down to $40 \%$. In construction, internal migrants accounted for $35 \%$ of those employed, non-migrants for $47 \%$, and cross-border migrants for $16 \%$, but once again, if only the migrants with up to ten years' residence are taken into account, the cross-border migrants rise to $49 \%$, the internal migrants go down to $29 \%$, and non-migrants (persons born in the province of Buenos Aires who moved to metropolitan Buenos Aires) go down to $21 \%$. Source: pooled data from the Permanent Household Survey.
} 
TABLE 12

Greater Buenos Aires: Composition of recent migrants, by origin and occupational category, in two branches of activity

(Percentages)

\begin{tabular}{|c|c|c|c|c|}
\hline \multirow[t]{2}{*}{ Branch } & \multirow{2}{*}{$\begin{array}{l}\text { Occupational } \\
\text { category }\end{array}$} & \multicolumn{2}{|c|}{ Migrants } & \multirow[t]{2}{*}{ Total } \\
\hline & & Internal & Cross-border & \\
\hline \multirow[t]{4}{*}{ Construction } & Employer & 2.2 & & 0.8 \\
\hline & Own-account work & 46.5 & 22.8 & 31.6 \\
\hline & Wage-earner & 51.3 & 77.2 & 67.6 \\
\hline & Total & 100.0 & 100.0 & 100.0 \\
\hline \multirow[t]{3}{*}{ Domestic service } & Own-account work & 23.8 & 16.1 & 19.5 \\
\hline & Wage-earner & 76.2 & 83.9 & 80.5 \\
\hline & Total & 100.0 & 100.0 & 100.0 \\
\hline
\end{tabular}

Source: Pooled data from the Permanent Household Survey (October figures) for Greater Buenos Aires, for 1993, 1995, 1997, 1999 and 2001.

TABLE 13

Greater Buenos Aires: Labour benefits received by wage-earners, according to migratory status

(Percentages)

\begin{tabular}{lccc}
\hline Extent of labour & & Wage-earners & Total \\
\cline { 2 - 3 } benefits & $\begin{array}{c}\text { Recent internal } \\
\text { migrants }\end{array}$ & $\begin{array}{c}\text { Recent cross-border } \\
\text { migrants }\end{array}$ \\
\hline All benefits & 55.3 & 26.1 & 44.5 \\
No benefits & 31.9 & 60.2 & 42.3 \\
Some benefits & 12.8 & 13.7 & 13.2 \\
Total & 100.0 & 100.0 & 100.0 \\
\hline
\end{tabular}

Source: Pooled data from the Permanent Household Survey (October figures) for Greater Buenos Aires, for 1993, 1995, 1997,1999 and 2001.

\section{Educational level and income}

The differences in educational level between cross-border and internal migrants were not evident among the total number of employed persons, but they were observable among those employed in domestic service and construction. Thus, among women working in domestic service, the proportion who had completed their secondary education was higher among cross-border than among internal migrants, while among men working in the construction sector, the educational level of migrants from the provinces of the interior was lower than that of cross-border migrants, although the difference was less marked than in the case of women (table 14). 
TABLE 14

Greater Buenos Aires: Composition of employed migrants (total and in two branches of activity), by educational level

(Percentages)

\begin{tabular}{llrrr}
\hline & \multicolumn{1}{c}{$\begin{array}{c}\text { Educational } \\
\text { level }\end{array}$} & \multicolumn{2}{c}{ Migrants } & Total \\
\cline { 3 - 5 } & Complete secondary education & 34.6 & 34.6 & 34.6 \\
& Incomplete secondary education & 65.4 & 65.4 & 65.4 \\
& Total & 100.0 & 100.0 & 100.0 \\
\hline Employed persons (men) & Complete secondary education & 32.3 & 30.5 & 31.7 \\
& Incomplete secondary education & 67.7 & 69.5 & 68.3 \\
& Total & 100.0 & 100.0 & 100.0 \\
\hline Employed persons (women) total & Complete secondary education & 38.5 & 39.1 & 38.7 \\
& Incomplete secondary education & 61.5 & 60.9 & 61.3 \\
& Total & 100.0 & 100.0 & 100.0 \\
\hline Domestic service (total) & Complete secondary education & 8.9 & 34.6 & 23.1 \\
& Incomplete secondary education & 91.1 & 65.4 & 76.9 \\
& Total & 100.0 & 100.0 & 100.0 \\
\hline Construction (total) & Complete secondary education & & 10.1 & 6.4 \\
& Incomplete secondary education & 100.0 & 89.9 & 93.6 \\
& Total & 100.0 & 100.0 & 100.0 \\
\hline
\end{tabular}

Source: Pooled data from the Permanent Household Survey (October figures) for Greater Buenos Aires, for 1993, 1995, 1997,1999 and 2001.

TABLE 15

\section{Greater Buenos Aires: Structure of educational level of recent employed migrants, by place of origin \\ (Percentages)}

\begin{tabular}{|c|c|c|c|c|c|c|}
\hline Educational level & Bolivia & Paraguay & Peru & Uruguay & & Total \\
\hline \multicolumn{7}{|l|}{ Incomplete } \\
\hline \multicolumn{7}{|l|}{ secondary } \\
\hline education & 70.8 & 88.7 & 21.1 & 64.3 & & 65 \\
\hline \multicolumn{7}{|l|}{ Complete } \\
\hline \multicolumn{7}{|l|}{ secondary } \\
\hline education & 29.2 & 11.3 & 78.9 & 35.7 & & 35 \\
\hline Total & 100.0 & 100.0 & 100.0 & 100.0 & & 100.0 \\
\hline Educational level & Corrientes & Chaco & Entre Ríos & Santiago & Tucumán & Total \\
\hline \multicolumn{7}{|l|}{ Incomplete } \\
\hline \multicolumn{7}{|l|}{ secondary } \\
\hline education & 67.6 & 79.6 & 56.8 & 87.6 & 82.8 & 70 \\
\hline \multicolumn{7}{|l|}{ Complete } \\
\hline \multicolumn{7}{|l|}{ secondary } \\
\hline education & 32.4 & 20.4 & 43.2 & 12.4 & 17.2 & 30 \\
\hline Total & 100.0 & 100.0 & 100.0 & 100.0 & 100.0 & 100.0 \\
\hline
\end{tabular}

Source: Pooled data from the Permanent Household Survey (October figures) for Greater Buenos Aires, for 1993, 1995, 1997,1999 and 2001. 
In the 1990s, cross-border migrants continued to show characteristics which were similar to those they had displayed in the previous two decades and which they shared with internal migrants: low levels of education and skills. The change which took place in the 1990s was that there was a visible deterioration in the educational levels of internal migrants compared with those from neighbouring countries.

Internal migrants mostly came from provinces where the levels of dropping-out, repetition and high age-for-grade in secondary education were markedly higher than in the other provinces, and especially the metropolitan area. Rather than an improvement in the levels of skills of cross-border migrants, what was observed was a relative decline in the levels of skills of native migrants arriving in Greater Buenos Aires from the 1980s on (data from the Federal Education Network of the Ministry of Education).

To some extent, cross-border migrants were more favourably placed as a source of labour for the branches of activity in which recent migrant workers have traditionally found employment: construction and domestic service. With levels of education that were comparable with and in some cases superior to internal migrants, and willing to accept more flexible wages and working conditions, they were in greater demand by employers than the latter. This is one possible explanation for the differential impact of the crisis on cross-border and internal migrants.

Throughout the period studied, cross-border migrants worked under less favourable conditions. Their monthly income was consistently below that of internal migrants, whether wage-earning or not, and their working hours were longer (table 16). Indeed, the total number of hours worked by cross-border migrants was gradually rising, even when the demand for labour was falling, whereas the total number of hours worked by internal migrants was going down, particularly in construction and domestic service, reflecting the decline in demand for this segment. The real income of cross-border migrants was consistently below the general average and that of internal migrants (figures 1 and 2).

TABLE 16

Greater Buenos Aires: Coefficients of hourly income, monthly income and hours worked by cross-border migrants, with respect to the corresponding values for recent internal migrants

\begin{tabular}{lllllllrrrrr}
\hline Cross-border migrants & Working conditions & 1993 & 1994 & 1995 & 1996 & 1997 & 1998 & 1999 & 2000 & 2001 \\
\hline Total & Hourly income & 0.86 & 0.80 & 0.69 & 0.77 & 0.77 & 0.91 & 0.70 & 0.81 & 0.77 \\
& Monthly income & 0.89 & 0.80 & 0.77 & 0.74 & 0.91 & 0.91 & 0.72 & 0.90 & 0.81 \\
& Hours worked & 1.02 & 1.00 & 1.06 & 0.93 & 1.14 & 1.00 & 1.07 & 1.06 & 1.10 \\
Wage-earners & Hourly income & 0.85 & 0.85 & 0.70 & 0.83 & 0.73 & 0.93 & 0.72 & 0.85 & 0.77 \\
& Monthly income & 0.89 & 0.79 & 0.77 & 0.73 & 0.89 & 0.91 & 0.78 & 0.89 & 0.83 \\
& Hours worked & 1.04 & 0.96 & 1.04 & 0.93 & 1.17 & 0.98 & 1.15 & 1.05 & 1.11
\end{tabular}

Source: Permanent Household Survey, October figures, Greater Buenos Aires.

FIGURE 1
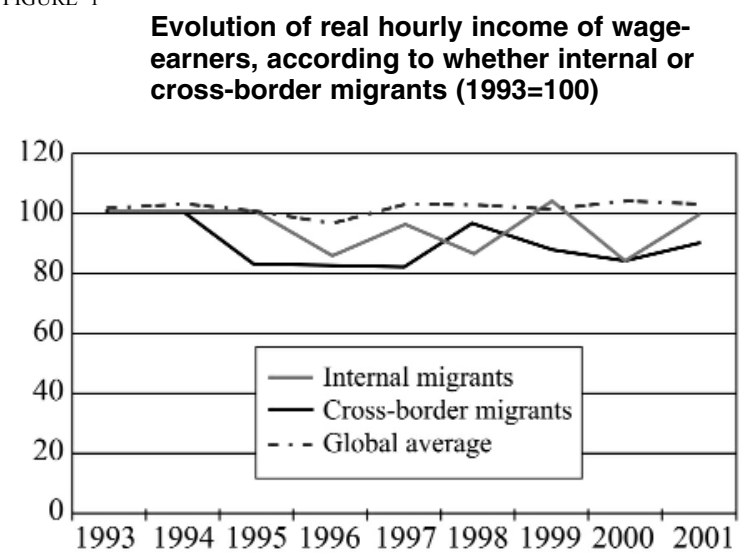

Source: Permanent Household Survey, October figures, Greater Buenos Aires.
FIGURE 2 Evolution of real monthly income of wage-
earners, according to whether internal or
cross-border migrants $(1993=100)$

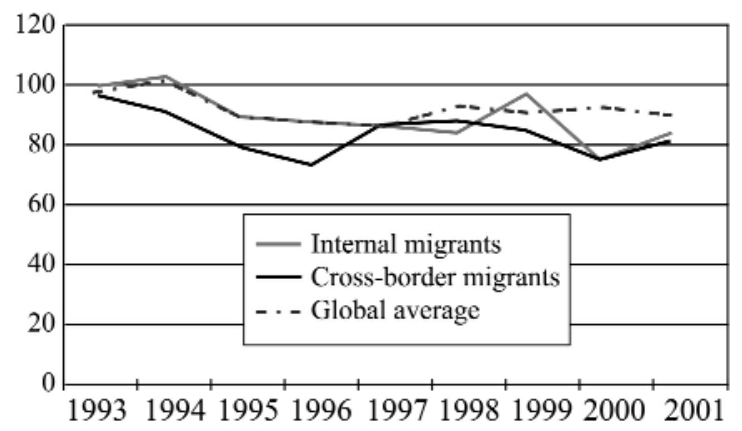

Source: Permanent Household Survey, October figures, Greater Buenos Aires. 


\section{IV}

\section{Conclusions}

The economic and labour market changes which took place in the 1990s affected the rates of migration to Greater Buenos Aires; throughout the decade, crossborder migration continued, whereas internal migration tended to diminish. The hypothesis that internal migrants may have returned home or withdrawn as a result of the decline in the demand for labour is worth investigating.

The changes in the form of insertion of internal migrants in the labour market were caused by the demand for labour, which, especially in the construction and domestic service sectors, gave preference to the incorporation of segments of the labour force with fewer demands for social protection in precarious jobs, under unfavourable working conditions and at low wages. As there had also been changes in the composition of the labour supply -a slight improvement in the educational level of cross-border migrants with respect to that of internal migrants- demand was reoriented towards the former. In the literature on migrations in the case of Argentina, several authors have put forward an explanation based on labour supply factors: thus, the hypothesis which holds that there was no competition between cross-border and internal migrants, and that the latter were not willing to accept those kinds of jobs, refers above all to the decades before the 1990s. As from the beginning of the 1990s, they argue, the rise in unemployment in the metropolitan area and the elimination of jobs may have caused competition between the two groups of workers. The role of demand in the competition between these two migrant segments does not appear to have been fully analyzed, however. In the present study, we consider that the most important factor has been the reorientation of the demand for labour because of the changes in the composition of the migrant flows: the rise in the educational level of cross-border migrants and the decline in that of internal migrants. This process led to the displacement of recent internal migrants from the sectors in which migrants typically work: there was a decline in the activity rate of internal migrants, which could well be a sign of discouragement, while the activity rate of cross-border migrants rose, although unemployment affected both groups. The cross-border migrants who were still employed took jobs with long hours and low hourly wages. Employment in the construction sector fell, and although in the domestic service sector the fall was not as great, in both sectors there was an increase in the proportion of cross-border migrants.

The increase in unemployment since the mid1980s has undoubtedly been a factor in the formation of a hard core of unemployed who have not been able to re-enter the labour force in the successive periods of economic reactivation. In diagnostic studies on the social situation in the metropolitan area, however, the size and extent of this hard core of unemployed -and hence of structural poverty- has often been minimized.

Our argument -which requires more detailed research-suggests that the above changes affected the composition of this sector of structural poverty and unemployment. In the 1970s and 1980s, structural poverty was associated with both migrant segments -internal and cross-border- although the incidence of poverty was greater among cross-border migrants. In the 1990s, however, the degree of unemployment and the persistence of poverty were more clearly limited to the internal migrant sector. Internal migrants were more likely to suffer situations of severe social privation, representing the first step towards exclusion. This is not a recent process, but rather a new pattern of distribution of access to income-generating activities which facilitated the reproduction of the "poverty trap". The replacement of under-privileged segments in the labour market deprives those thus displaced of possibilities of entering that market again and, in general, obtaining income.

This process has been building up a new social setting in which there are increasingly marked divisions between those holding precarious jobs and those who are unemployed and are simply no longer taken into account for employment. 
Appendix

Characteristics of the Permanent Household Survey carried out by the National Institute of Statistics and Censuses (INDEC).

This survey is carried out on the basis of a set of samples from the main urban agglomerations in the country, representing approximately $70 \%$ of the national urban population. The population of Greater Buenos Aires, which comprises the city of Buenos Aires and 19 areas of the Buenos Aires conurbation, represents $30 \%$ of the total population of the country and approximately $40 \%$ of the total urban population. The data are collected twice a year, in May and October, and the units of observation are households. The household survey of Greater Buenos Aires represents $100 \%$ of the population of that agglomeration. The information collected corresponds to characteristics of the households and the individuals in them. The first characteristics include in particular the size and composition of the household and the characteristics of the dwelling, while the second set of characteristics includes demographic, labour, income, educational and migration variables.

\begin{tabular}{|c|c|c|c|c|}
\hline \multirow[b]{3}{*}{$\begin{array}{l}\text { Province } \\
\text { or country }\end{array}$} & \multicolumn{4}{|c|}{$\begin{array}{l}\text { Greater Buenos Aires: Composition of recent resident migrants, } \\
\text { by place of origin } \\
\text { (Percentages) }\end{array}$} \\
\hline & \multicolumn{2}{|c|}{ October 1993} & \multicolumn{2}{|c|}{ October 2000} \\
\hline & $\begin{array}{l}\text { Recent internal } \\
\text { migrant }\end{array}$ & $\begin{array}{c}\text { Recent } \\
\text { cross-border } \\
\text { migrant }\end{array}$ & $\begin{array}{l}\text { Recent internal } \\
\text { migrant }\end{array}$ & $\begin{array}{c}\text { Recent } \\
\text { cross-border } \\
\text { migrant }\end{array}$ \\
\hline Corrientes & 13.6 & & 8.4 & \\
\hline Chaco & 16.2 & & 9.2 & \\
\hline Entre Ríos & 6.9 & & 7.5 & \\
\hline Santiago & 11.0 & & 9.9 & \\
\hline Tucumán & 7.7 & & 7.8 & \\
\hline Misiones & 11.4 & & 21.7 & \\
\hline $\begin{array}{l}\text { Other provincial } \\
\text { migrants }\end{array}$ & 33.2 & & 35.5 & \\
\hline Total, provincial migrants & 100.0 & & 100.0 & \\
\hline Bolivia & & 15.5 & & 16.5 \\
\hline Paraguay & & 42.6 & & 42.4 \\
\hline Peru & & 5.7 & & 27.4 \\
\hline Uruguay & & 27.2 & & 7.4 \\
\hline Others & & 9.0 & & 6.3 \\
\hline Total, cross-border migrants & & 100.0 & & 100.0 \\
\hline
\end{tabular}

Source: Permanent Household Survey. 
FIGURE A.1

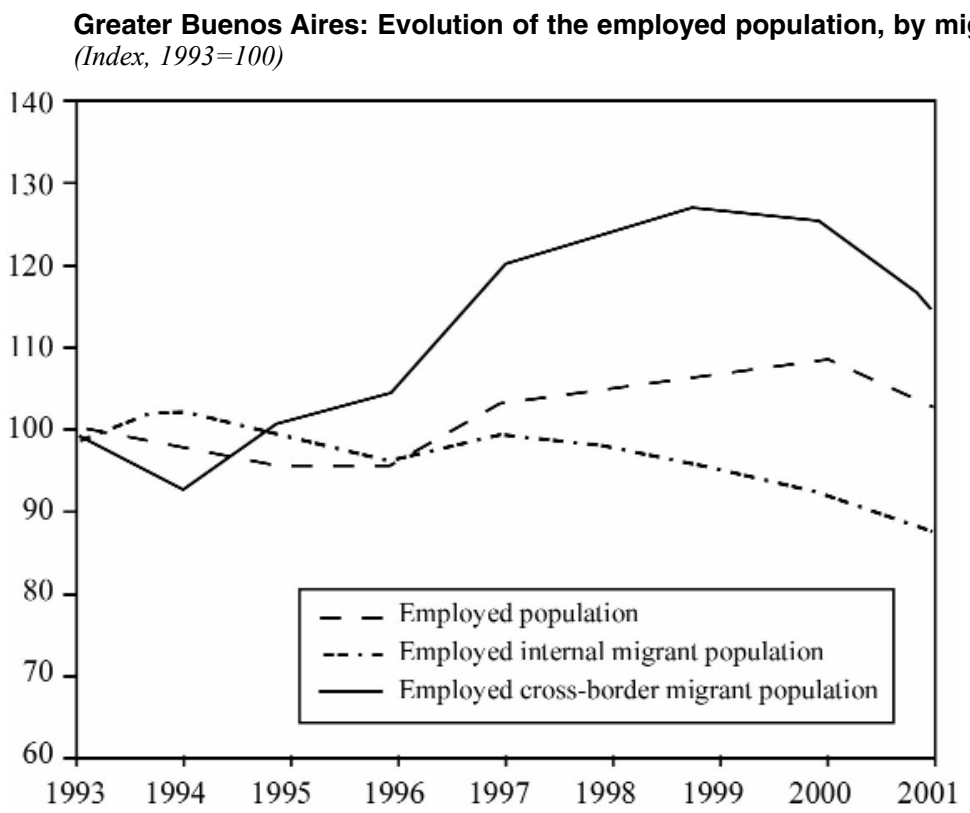

Source: Permanent Household Survey, October figures, Greater Buenos Aires.

FIGURE A.2 Greater Buenos Aires: $90 \%$ confidence intervals of rates of open unemployment of male cross-border and internal migrants ${ }^{a}$

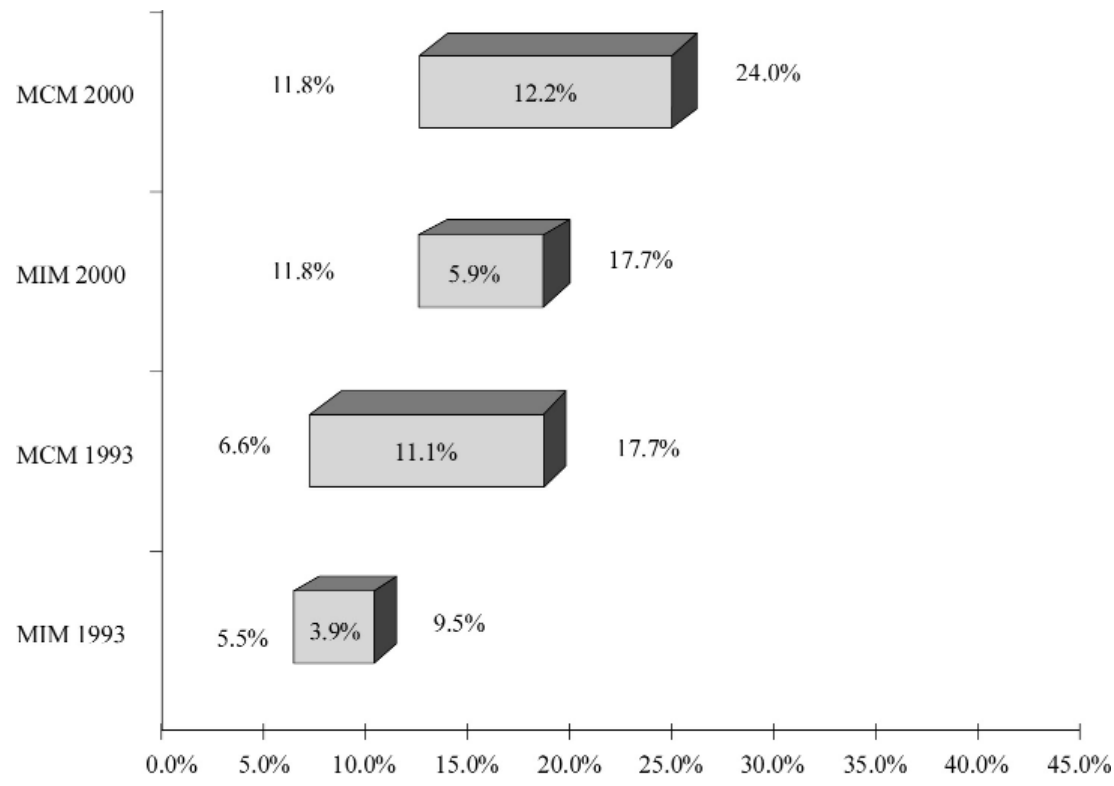

Source: Permanent Household Survey, October figures, Greater Buenos Aires.

a $\mathrm{MCM}=$ Male cross-border migrants. MIM = Male internal migrants. 
FIGURE A.3

Greater Buenos Aires: $90 \%$ confidence intervals of rates of open unemployment of female cross-border and internal migrants ${ }^{a}$

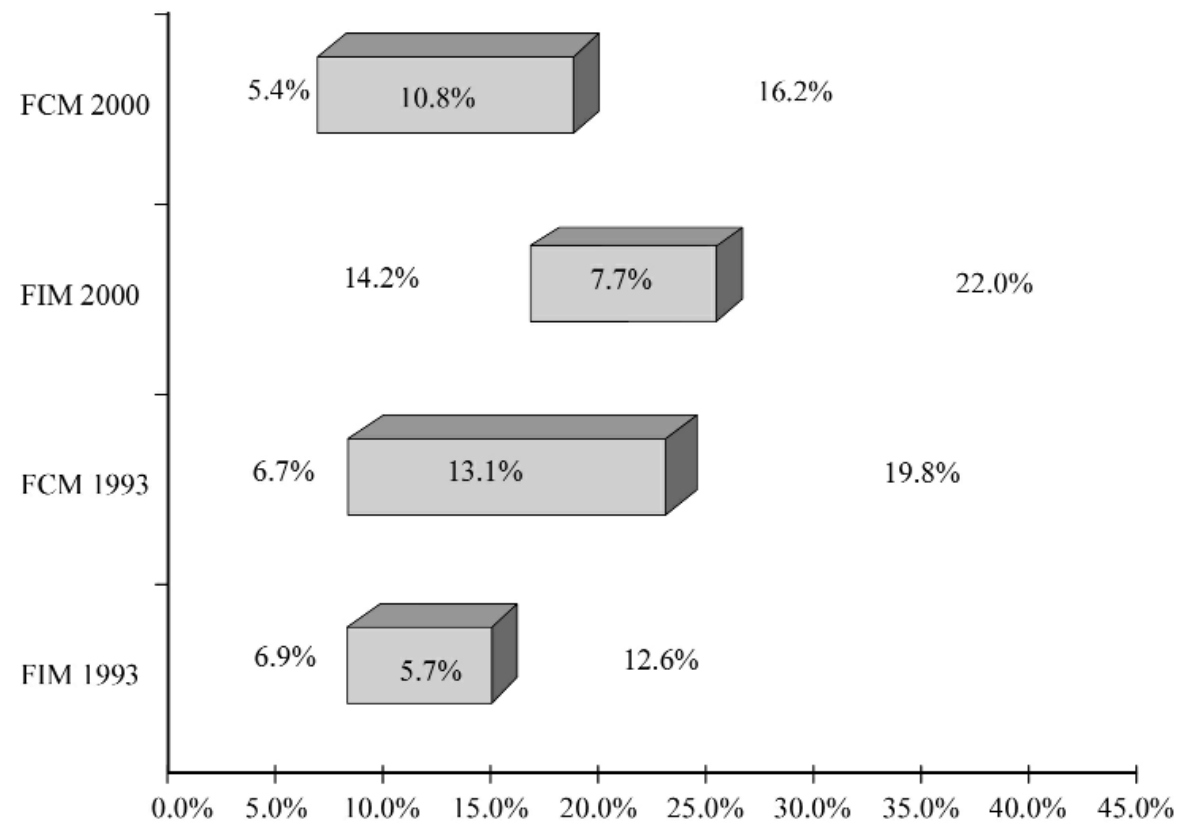

Source: Permanent Household Survey, October figures, Greater Buenos Aires.

a $\mathrm{FCM}=$ Female cross-border migrants. $\mathrm{FIM}=$ Female internal migrants.

TABLE A.2

Greater Buenos Aires: Ordinary least squares linear regression analysis ${ }^{a}$

Independent variable: Rate of participation of recent cross-border migrants in the economically active population (EAP)

Dependent variables:

(1) Rate of employment of young recent internal migrants without complete secondary education

(2) Rate of employment of young non-recent internal migrants without complete secondary education

(3) Rate of employment of young recent cross-border migrants without complete secondary education

(4) Rate of employment of older non-migrants without complete secondary education

(5) Activity rate of young non-migrants without complete secondary education

(6) Activity rate of young cross-border migrants without complete secondary education

(7) Activity rate of older non-recent cross-border migrants without complete secondary education

\begin{tabular}{lccccccc}
\hline $\begin{array}{l}\text { Independent } \\
\text { variable }\end{array}$ & $\begin{array}{c}\text { Dependent } \\
\text { variable } \\
(1)\end{array}$ & $\begin{array}{c}\text { Dependent } \\
\text { variable } \\
(2)\end{array}$ & $\begin{array}{c}\text { Dependent } \\
\text { variable } \\
(3)\end{array}$ & $\begin{array}{c}\text { Dependent } \\
\text { variable } \\
(4)\end{array}$ & $\begin{array}{c}\text { Dependent } \\
\text { variable } \\
(5)\end{array}$ & $\begin{array}{c}\text { Dependent } \\
\text { variable } \\
(6)\end{array}$ & $\begin{array}{c}\text { Dependent } \\
\text { variable } \\
(7)\end{array}$ \\
\hline $\begin{array}{l}\text { Participation of } \\
\text { recent cross-border } \\
\text { migrants in EAP }\end{array}$ & $\begin{array}{c}-13.537 \\
(7.942)\end{array}$ & $\begin{array}{l}11.241 \\
(6.378)^{\mathrm{b}}\end{array}$ & $\begin{array}{c}-21.103 \\
(10.167)^{\mathrm{b}}\end{array}$ & $\begin{array}{c}4.654 \\
(2.229)^{\mathrm{b}}\end{array}$ & $\begin{array}{c}-9.867 \\
(3.885)^{\mathrm{c}}\end{array}$ & $\begin{array}{c}-17.181 \\
(8.030)^{\mathrm{c}}\end{array}$ & $\begin{array}{c}13.106 \\
(5.523)^{\mathrm{c}}\end{array}$ \\
\hline $\mathrm{R}^{2}$ & 0.154 & 0.163 & 0.212 & 0.214 & 0.287 & 0.222 & 0.260 \\
\hline
\end{tabular}

Number of

observations: 18

Source: Prepared by the authors on the basis of May and October figures for Greater Buenos Aires from October 1993 to May 2002.

a The figures in parentheses correspond to the standard error. The age groups were as follows: young (between 16 and 29), adult (between 30 and 44), older (over 45).

b Significant at $10 \%$.

c Significant at $5 \%$. 
Dependent variables:

(1) Rate of employment of young recent internal migrants without complete secondary education

(2) Rate of employment of young non-recent internal migrants without complete secondary education

(3) Rate of employment of adult non-recent internal migrants without complete secondary education

(4) Rate of employment of older non-migrants without complete secondary education

(5) Activity rate of young recent cross-border migrants without complete secondary education

\begin{tabular}{|c|c|c|c|c|c|}
\hline $\begin{array}{l}\text { Independent } \\
\text { variable }\end{array}$ & $\begin{array}{l}\text { Dependent } \\
\text { variable } \\
\text { (1) }\end{array}$ & $\begin{array}{l}\text { Dependent } \\
\text { variable } \\
\text { (2) }\end{array}$ & $\begin{array}{l}\text { Dependent } \\
\text { variable } \\
\text { (3) }\end{array}$ & $\begin{array}{l}\text { Dependent } \\
\text { variable } \\
\text { (4) }\end{array}$ & $\begin{array}{l}\text { Dependent } \\
\text { variable } \\
\text { (5) }\end{array}$ \\
\hline $\begin{array}{l}\text { Percentage of recent } \\
\text { cross-border migrants in total } \\
\text { employed population }\end{array}$ & $\begin{array}{l}-11.170 \\
(7.861)\end{array}$ & $\begin{array}{c}11.988 \\
(6.031)^{b}\end{array}$ & $\begin{array}{c}7.299 \\
(4.285)\end{array}$ & $\begin{array}{c}3.911 \\
(2.224)^{b}\end{array}$ & $\begin{array}{l}-18.648 \\
(7.463)^{\mathrm{c}}\end{array}$ \\
\hline$\overline{\mathrm{R}^{2}}$ & 0.112 & 0.198 & 0.154 & 0.162 & 0.281 \\
\hline
\end{tabular}

Number of observations: 18

Source: Prepared by the authors on the basis of May and October figures for Greater Buenos Aires from October 1993 to May 2002.

a The figures in parentheses correspond to the standard error. The age groups were as follows: young (between 16 and 29), adult (between 30 and 44), older (over 45).

b Significant at $10 \%$.

c Significant at $5 \%$.

\section{Pooling of survey data}

The methodological strategy chosen for this part of the study, which consists of forming a pool of survey data, makes it possible to carry out tabulations at a higher level of disaggregation than that which is usual for working on the figures obtained separately in each compilation of data by the Permanent Household Survey (i.e., each "wave" of data), without causing the results of this operation to lose their significance. The assumption on which the use of this procedure is based is that the 1990s was homogeneous in terms of incentives and disincentives and that the changes that could occur in each period are only small and therefore do not alter the final balance. The pooling of data was carried out using the October figures for 1993, 1995, 1997, 1999 and 2001, and between each of them there was a complete rotation of the households responding, thus avoiding the overlapping of data corresponding to the same individuals.

Migrations from neighbouring countries have traditionally represented only a small proportion of the total population: $2.4 \%$ up to 1980 and $2.5 \%$ in 1991. The flow of migrants from neighbouring countries, which had grown in the first half of the 1970s, slackened between 1975 and 1980 .

Total population growth in Argentina has shown a downward trend: the average annual rates in the $1970 \mathrm{~s}, 1980 \mathrm{~s}$ and $1990 \mathrm{~s}$ were $1.8 \%, 1.6 \%$ and $1 \%$, respectively (INDEC, 1970, 1980 and 1991 censuses). ${ }^{18}$ As international migrations from non-neighbouring countries went down, the proportion of migrants from neighbouring countries in total migration has increased, amounting to $52 \%$ in 1991 (INDEC, 1991).

(Original: Spanish)

\footnotetext{
${ }^{18}$ For the period from 1991 to 2001, the rate of variation has been estimated on the basis of preliminary data from the 2001 National Population Census.
} 


\section{Bibliography}

Benencia, R. (2000): Argentina: la problemática social de la migración limítrofe, Comercio exterior, vol. 50, No. 3, Mexico City, Banco Nacional de Comercio Exterior (BANCOMEXT).

Benencia, R. and A. Gazotti (1995): Migración limítrofe y empleo: precisiones e interrogantes, Estudios migratorios latinoamericanos, vol. 10, No. 31, Buenos Aires, Centro de Estudios Migratorios Latinoamericanos (CEMLA).

CELADE (1998): Latin America: population projections, 19702050, Demographic Bulletin, No. 62, LC/DEM/G.180, Santiago, Chile.

CELS (Center for Legal and Social Studies) (1998): Informe anual, Buenos Aires. (2000): Informe anual, Buenos Aires.

Cortés, R. (1985): Cambios en el mercado de trabajo urbano en la Argentina: 1974-1983, "Documentos e Informes de Investigación" series, No. 14, Buenos Aires, Latin American Faculty of Social Sciences (FLACSO).

INDEC (National Institute of Statistics and Censuses) (1980): Censo Nacional de Población, 1980, Buenos Aires. (1991): Censo Nacional de Población, 1991, Buenos Aires. (various years): Encuesta Permanente de Hogares, Buenos Aires.

Lattes, A. (1997): La dinámica demográfica y la migración en la evolución reciente de la actividad económica en el Area Metropolitana de Buenos Aires, Buenos Aires, unpublished.

Maguid, A. (1990): Argentina: migración y pobreza durante la década del 80, Buenos Aires, National Council for Scientific nd Technical Research (CONICET).

(1995): Migrantes limítrofes en Argentina: su inserción e impacto en el mercado de trabajo, Estudios del trabajo, No. 10, Buenos Aires, Asociación Argentina de Especialistas en Estudios del Trabajo (ASET).
(2001): El chivo expiatorio. Problemas de empleo, Encrucijadas, vol. 1, No. 7, Buenos Aires, University of Buenos Aires.

Mármora, L. (1977): Política e investigación en el proceso de planificación migratoria, Santiago, Chile, Programme of Social Research on Population in Latin America (PISPAL)/ Population Division (CELADE).

(1994): Desarrollo sostenido y políticas migratorias: su tratamiento en los espacios latinoamericanos de integración, Revista de la OIM sobre Migraciones en América Latina, vol. 12, No. 1, Santiago, Chile, Center for Information on Migrations in Latin America (CIMAL).

Marshall, A. (1977): Inmigración, demanda de fuerza de trabajo y estructura ocupacional en el área metropolitana argentina, Desarrollo económico, vol. 17, No. 65, Buenos Aires, Institute of Economic and Social Development (IDES).

(2000): Política inmigratoria y el mercado de trabajo, Memorias de las IV Jornadas Argentinas de Estudios de Población, Resistencia, Chaco.

Marshall, A. and D. Orlansky (1983): Inmigración de países limítrofes y demanda de mano de obra en la Argentina, 1940-1980, Desarrollo económico, vol. 23, No. 89, Buenos Aires, Institute of Economic and Social Development (IDES).

Montoya, S. and M. Perticara (1995): Los migrantes de países limítrofes en los mercados de trabajo urbanos, Estudios, No. 75, Córdoba, Instituto de Estudios Económicos sobre la Realidad Argentina y Latinoamericana (IEERAL), OctoberDecember.

Novick, S. (2001): Un país ¿receptor? Políticas migratorias nacionales, Encrucijadas, vol. 1, No. 7, Buenos Aires, University of Buenos Aires. 